\title{
Periodontitis as a risk factor of stroke - literature review
}

\author{
Małgorzata Majka Kulińska-Michalska', Natalia Lewkowicz \\ ${ }^{1}$ Department of General Dentistry, Medical University of Lodz
}

Kulińska-Michalska M.M, Lewkowicz N. Periodontitis as a risk factor of stroke - literature review. Med Og Nauk Zdr. 2017 ; 23(2): 138-142. doi: $10.26444 / \mathrm{monz} / 74775$

\section{Abstract}

Introduction and objective. Periodontitis is an inflammatory condition affecting tooth-supporting tissues that can interfere with the course of systemic diseases. Currently, the main interest has focused on the interaction between periodontal disease and cardiovascular diseases.

State of knowledge. The paper presents current views on the relationship between periodontitis and stroke, based on a search in the Medline and Pubmed databases from 2000-2016. Numerous studies have shown that periodontal inflammation may mediate the formation of ischemic stroke by promoting the growth of atherosclerotic plaque. Periodontitis was assumed to be an independent risk factor for stroke.

Conclusions. Prevention and treatment of periodontal disease might inhibit the development of the inflammatory process and consequently the formation of atherosclerotic plaque.

\section{Key words}

periodontitis, stroke, risk factors

\section{INTRODUCTION}

In 1996, Offenbacher introduced the concept of periodontal medicine, exploring the relationship between periodontal disease and systemic diseases [1]. During following 20 years, many studies were performed to discover the association between periodontitis and cardiovascular diseases, diabetes, pregnancy complications or rheumatoid arthritis [2]. Currently, the main interest is focused on the interaction between periodontal disease and cardiovascular diseases.

The two main forms of periodontal disease are gingivitis and periodontitis. Gingivitis is primarily caused by dental plaque, and affects gingival tissue only, while connective tissue attachment and alveolar bone remain intact. Conversely, periodontitis is a disease of multifactorial etiology with a complex clinical picture, manifested by the gradual, irreversible destruction of tooth-supporting tissues (gingiva, periodontal ligament, bone) which leads to the loss of teeth $[2,3]$. Periodontitis disease is a common condition that affects about $90 \%$ of the worldss population [4]. Using the community periodontal index (CPI), one of the most frequent used indicators of periodontal disease, the incidence of periodontal disease can be evaluated. According to a recent study on the population of Europe, the distribution of CPI codes in the Polish population were as follows: CPI-0 (1.1\%), CPI-1 (12.6\%), CPI-2 (22.9\%), CPI-3 (40.7\%), CPI-4 (16.5\%), with worse values present only in Germany and Croatia [5]. The average number of teeth in patients aged 65-74 in Poland was 6.7, compared to 18.7 in the USA and 17.6 in Switzerland [5]. The proportion of toothless individuals in Poland was $43.9 \%, 23.9 \%$ in the USA and $13.8 \%$ in Switzerland [5].

It is believed that periodontitis results from the interaction of genetic factors (host susceptibility) and environmental factors (microbial imbalance in the oral cavity, smoking) [4].

Adres do korespondencji: Małgorzata Kulińska-Michalska, Department of General Dentistry, Medical University of Lodz, ul. Pomorska 251, 92-213 Łódź, Ołowiana 44, 91-614 Łódź, Polska

E-mail: malgorzatakulinskam@gmail.com

Nadesłano: 20 kwietnia 2017; zaakceptowano do druku: 14 czerwca 2017
In the course of periodontitis, there is a systemic increase in pro-inflammatory markers (IL-1, PGE, TNF, IL-6) as a result of an immune response against Gram-negative bacteria (periodontal pathogens), which is a common etiological agent for arteriosclerosis and periodontitis $[6,7$, 8]. The complications of advanced atherosclerosis include myocardial infarction and stroke. Stroke is a sudden onset of focal or generalized brain dysfunction, lasting more than 24 hours, and due to only vascular reasons associated with cerebral blood flow [9]. Stroke in terms of the underlining mechanisms is divided into $[10,11,12]$ :

1) ischemic stroke - caused by arterial obstruction and reduced blood supply to the brain. This is due to atherosclerotic plaques in large and medium-sized arteries supplying the brain (p. Cervical, t. Cords), or large and medium cerebral arteries and changes in the small vessels of the brain (cerebral sinus);

2) haemorrhagic stroke - caused by intracerebral vessel rupture. A common cause of stroke is high blood pressure;

3) venous stroke - following vein thrombosis.

Annually, there are about 60,000 new cases of stroke in Poland. Stroke affects 177.3 men out of 100,000 and 125 women out of 100,000 in Poland [13]. Respectively, the mortality in patients with stroke is 106.4 per 100,000 in men and 78.7 per 100,000 in women [13]. According to current statistics, stroke is the third leading cause of death in Poland. Initial stroke diagnosis involves magnetic resonance imaging or computer tomography in order to determine the type of stroke [14]. Complications following a stroke include a number of dysfunctions, speech deficiencies, various type of paralysis and palsy [15]. The risk of recurrent stroke in patients after stroke is statistically higher [9].

The first case-control study indicating a link between periodontitis and a history of stroke comes from 1989 [16]. Since then, a series of case-control studies and cohort studies evaluating this relationship have been performed. It has been shown that both pathologies are social and have common risk factors. The in-depth exploration of these issues will allow 
the implementation of appropriate preventive and curative measures in the field of periodontology and neurology.

\section{STATE OF KNOWLEDGE}

Atherosclerosis is a chronic inflammatory disease of the arteries. It is characterized by blood vessel wall inflammatory infiltration, lipid accumulation and fibrosis $[9,17]$. The pathogenesis of atherosclerosis involves four stages:

1) damage to vascular endothelium;

2) release of mitogenic factors by the platelets and monocytes; 3) phagocytosis of lipids;

4) formation of atherosclerotic plaque [18].

Periodontal pathogens, such as, Porphyromonas gingivalis (P.g.), Tannerella forsythia (T.f.), and Treponema denticola (T.d.), may affect both the initial phase as well as the further development of atherosclerotic plaque [19, 20,21]. Periodontal pathogens can enter the bloodstream by acting directly on the vascular endothelium. Transient bacteraemia may be associated with the act of chewing, tooth brushing or dental procedure $[22,23]$. One of the factors affecting the development of atherosclerotic lesions is a lipopolysaccharide (LPS), which is released during the disintegration of bacteria. LPS triggers a metabolic cascade with an increase of PGE, TNF, IL-1, matrix metalloproteinases (MMP) and other proteolytic enzymes which, as a consequence, leads to the destabilization of atherosclerotic plaques and proliferation of smooth muscle cells in the arteries [19, 24, 25, 26, 27]. An ongoing inflammatory process in the periodontium increases TNF and IL- 6 in the periodontal pocket fluid and in the serum. These cytokines stimulate the production of CRP in the liver, which in turn, is a risk factor for atherosclerotic plaques $[28,29,30]$. The bacteria $P$. gingivalis and S. sanguis, express on their surface a platelet aggregation-associated protein (PAAP), which initiates the adhesion and aggregation of platelets, regardless of calcium $[25,31,32]$. Another theory worth noting is a 'pathogen burden' which specifies that the risk of atherosclerosis is proportional to the number of infections with various microorganisms [33].

One of the latest concepts is the molecular mimicry, referring to an inappropriate immune response to bacterial HSP60 which results in host HSP60 destruction and damage to the vascular endothelium [33]. The risk factors for developing atherosclerotic plaque include cigarette smoking, low physical activity, elevated levels of LDL and triglycerides, low HDL levels, diabetes, obesity, high blood pressure and infectious agents, as well as non-modifiable risk factors, such as age over 45 and gender. Clinically, atherosclerotic plaque may initiate thrombus formation which is an embolic risk. Intraplaque haemorrhage leads to a sudden increase in its volume, narrowing the artery and causing myocardial infarction.

The consequences of the deposition of atheromatous plaques depend on their location. The formation of atherosclerotic plaques in the carotid arteries of the brain can lead to stroke [18]. Atherosclerosis, stroke and periodontitis possess common risk factors: age, male gender, cigarette smoking, diabetes and obesity (Tab. 1) $[15,34,35,36,37,38,39]$. So far, studies have allowed us to conclude that inflammation existing in the periodontium can lead to the development of atherosclerosis, both directly and indirectly. Studies
Table 1. Risk factor for stroke, atherosclerosis and periodontitis

\begin{tabular}{lccc}
\hline Risk factor & Stroke & Atherosclerosis & Periodontitis \\
\hline Age & + & + & + \\
\hline Male & + & + & + \\
\hline Black race & + & & + \\
\hline Genetic polymorphisms & + & + & + \\
\hline Periodontal pathogens & & & + \\
\hline Smoking & + & + & + \\
\hline Diabetes & + & + & + \\
\hline Obesity & + & + & + \\
\hline Socioeconomic status & & + & + \\
\hline Stress & & + & + \\
\hline Hypertension & + & + & \\
\hline Myocardial diseases & + & & \\
\hline Internal carotid artery stenosis & + & & \\
\hline Vascular diseases & + & & \\
\hline Increase fibrinogen levels & + & & \\
\hline Hypothyroidism & + & \\
\hline
\end{tabular}

confirmed that the thickness of the plaque corresponds to the severity of periodontal disease. In terms of the infection total load theory, the risk of atherosclerosis is proportional to the number of infections with various microorganisms [40]. Therefore, elimination of inflammation by treating periodontal disease may reduce the risk of the atherosclerotic plaque formation.

Cohort studies. Cohort (prospective) studies are based on the assessment of the incidence of a particular disease, depending on the exposure to the probable risk factor. From a total of eight cohort studies published from 2000-2016, four were included into the following analysis (Tab. 2). Studies were included if they fulfilled the following inclusion criteria:

1) stroke was diagnosed according to the internationally accepted criteria;

2) periodontitis as one of the outcomes of interest;

3) periodontitis fulfilling the definition of Tonetti and Claffey [41].

Survey-based studies have been omitted due to the limited credibility of the research.

Lafon et al., based on a four-year observation of 95 individuals, have stated that the inflammatory process occurring in patients with periodontal disease contributes to an increased risk of ischemic stroke [42]. In the study, various periodontal indices were measured, such as plaque index (PI), gingival index (GI), probing depth (PD), bleeding on probing (BoP), number of teeth and radiographic bone loss. The authors demonstrated a link between an increased BoP rates and bone loss and ischemic stroke [42]. Wu et al. conducted a 10-year study on a group of 9,962 individuals aged 25-74 [43]. They showed that the increase in the PD and number of teeth correlated with the risk of both haemorrhagic and ischemic stroke[43]. Jimenez et al. studied a group of 1,137 individuals over 24 years of age [44]. They examined the number of periodontal indices, including PI, GI and PD, and confirmed radiologically periodontal bone loss, showed that bone loss in men $<65$ years of age was significantly associated with the occurrence of stroke and transient ischemic attack 
Table 2. Cohort studies

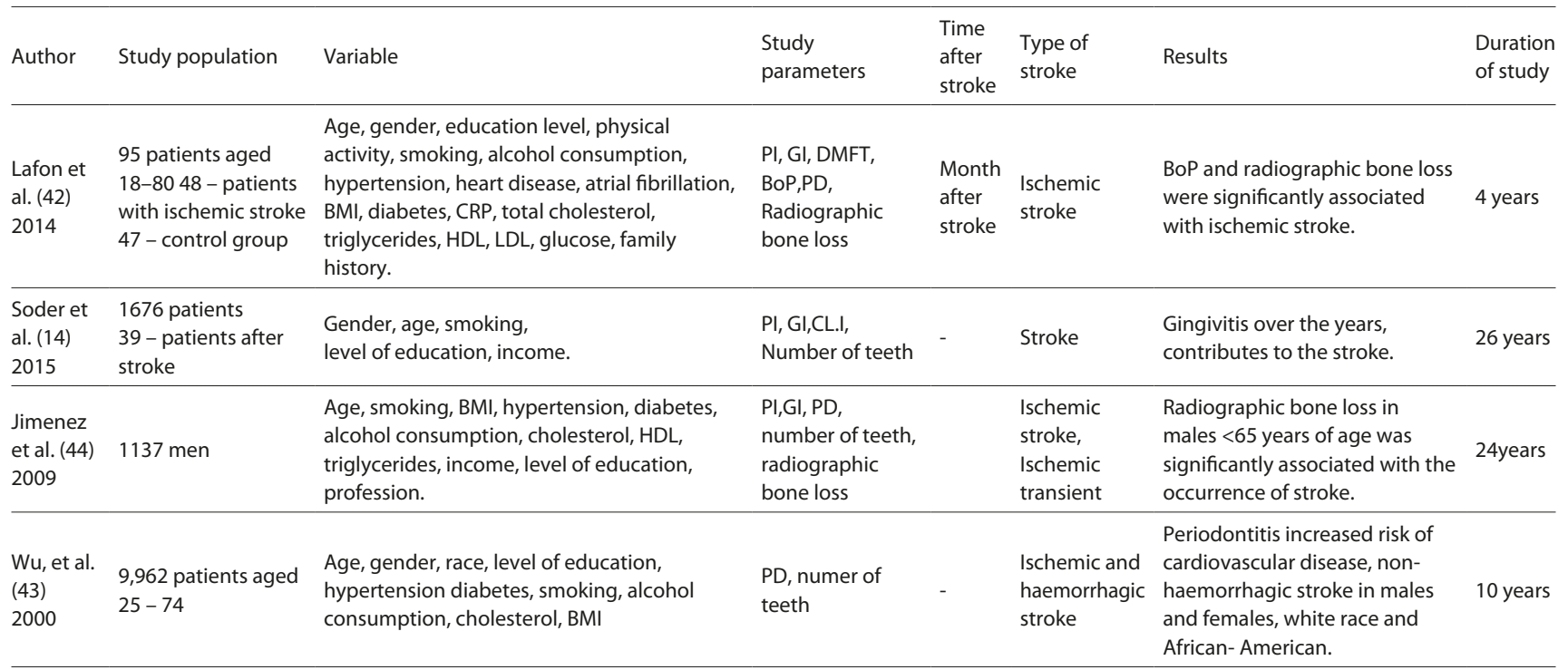

[44]. To-date, the longest observation was performed by Soder et al. - over 26 years in a group of 1,676 patients which demonstrated that in patients with gingivitis the risk of stroke rises significantly over the years [15]. Gingival index was significantly higher in patients with stroke, but no relationship between stroke and number of missing teeth were conducted [15].

Among all follow-up studies, researchers took into account patients' age, gender, smoking habits and alcohol consumption. A large group of researchers assessed the physical activity of patients, their level of education, HDL and LDL levels, as well as genetic predisposition to cardiovascular disease. The authors showed that the subjects with a lower number of teeth, mostly men, were more likely to suffer a stroke $[42,43,44]$. In addition, all the subjects were smokers who admitted to low physical activity and increased alcohol consumption $[42,43,44]$. Lafon et al. showed that the level of CRP in patients after stroke with periodontal disease is significantly higher compared with the control group, and that treatment of periodontal disease reduces the level of CRP [42]. The cohort study performed by Soder et al. seems to be of the greatest importance, not only because of its durations (26 years) and sample size, but also because of the detailed documentation of periodontal status of the studied group which increases the reliability of the achieved results [15].

Case-control studies. Case-control (retrospective) studies are seeking for a relationship between the exposure and the onset of a disorder. From a total of 10 case-control studies published from 2000-2016, seven were included into the following analysis (Tab. 3). Studies were included if they fulfilled the following inclusion criteria:

1) stroke was diagnosed according to the internationally accepted criteria;

2) periodontitis as one of the outcomes of interest;

3) periodontitis fulfilling the definition of Tonetti and Claffey [41].

Survey-based studies have been omitted due to the limited credibility of the research.
Budin et al. demonstrated in the group of 160 patients that the oral hygiene index (OHI), PD and GI decayedmissing-filled teeth (DMFT) index were significantly higher in patients after stroke, compared to a control group [12]. The authors have shown that periodontitis is an independent risk factor for ischemic stroke. Abolfazli et al. showed that patients after an ischemic stroke had a greater loss of clinical attachment level (CAL) than the control group. At the same time, they found no relationship between ischemic stroke and gingivitis [45]. Hashemipour and Pradeep each studied an average number of patents [46,47]; in turn, Hashemipour et al. showed that moderate and advanced periodontitis occurred more frequently in patients after stroke, based on PI, GI and CAL examination [47]. Sim et al., based on a group of 479 patients, established a strong link between stroke and periodontal disease in patients with CAL> $6 \mathrm{~mm}$. This relationship was significant in the patients under 60 years of age with normal blood pressure [48]. Research conducted by Dorfer et al., based on the assessment of DMFT, CAL, PD, GI, PI and radiological bone loss, demonstrated that patients who have had an ischemic stroke had an increased loss of CAL, compared to the control group [49]. The risk of ischemic stroke increased 7.4 times when CAL loss was $>6 \mathrm{~mm}, 18.3$ times when GI was $>1.2$, and 3.6 times when radiographic bone loss was present [49]. Grau et al., on the group of 771 individuals, showed that patients with advanced periodontitis where CAL was $>6 \mathrm{~mm}$ were 4.3 times more likely to have an ischemic stroke. They also showed a greater relationship between ischemic stroke and advanced periodontal disease in men under 60 years of age [50].

Among the presented case-control studies, all authors, except Budin et al., evaluated the periodontal status based on the loss of CAL. Smin et al. performed measurements at six sites of each tooth present, while other researchers evaluated four sites $[45,46,48,49,50]$. All these researchers have confirmed that the risk of stroke increases proportionally to the loss of CAL. Case-control studies confirm that periodontal disease is an independent risk factor for stroke. 
Table 3. Case-control studies

\begin{tabular}{|c|c|c|c|c|c|c|}
\hline Author & Study population & Variable & $\begin{array}{l}\text { Study } \\
\text { parameters }\end{array}$ & $\begin{array}{l}\text { Time after } \\
\text { stroke }\end{array}$ & Type of stroke & Results \\
\hline $\begin{array}{l}\text { Sim et al. (48) } \\
2008\end{array}$ & $\begin{array}{l}479 \text { patients } \\
265 \text { - non-fatal stroke } \\
214 \text { - control group }\end{array}$ & $\begin{array}{l}\text { Age, gender, income, alcohol } \\
\text { consumption, education level, smoking, } \\
\text { hypertension, diabetes, BMI, family history }\end{array}$ & CAL, DMFT & $\begin{array}{l}\text { From } 3 \\
\text { months to } \\
\text { a year }\end{array}$ & $\begin{array}{l}\text { Non-fatal } \\
\text { ischemic and } \\
\text { hemorrhagic } \\
\text { stroke }\end{array}$ & $\begin{array}{l}\text { Periodontitis is significantly } \\
\text { associated with occurrence of } \\
\text { stroke in patients }<60 \text { years. }\end{array}$ \\
\hline $\begin{array}{l}\text { Abolfazli et al. } \\
(45) \\
2011\end{array}$ & $\begin{array}{l}200 \text { patients } \\
100 \text { - patients with } \\
\text { ischemic stroke } \\
100 \text { - control group }\end{array}$ & $\begin{array}{l}\text { Age, gender, hypertension, smoking, } \\
\text { diabetes, atrial fibrillation, obesity, } \\
\text { cardiovascular disease family history }\end{array}$ & CAL, GI & $\begin{array}{l}\text { About } 3 \\
\text { days after }\end{array}$ & $\begin{array}{l}\text { Ischemic } \\
\text { stroke }\end{array}$ & $\begin{array}{l}\text { Periodontitis is an } \\
\text { independent risk factor for } \\
\text { ischemic stroke in men. }\end{array}$ \\
\hline $\begin{array}{l}\text { Dorfer et al. (49) } \\
2004\end{array}$ & $\begin{array}{l}603 \text { patients aged } 18-75 \text {; } \\
303 \text { patients with ischemic } \\
\text { stroke; } \\
300 \text { - control group }\end{array}$ & $\begin{array}{l}\text { Age, gender, hypertension, smoking, } \\
\text { diabetes, atrial fibrillation, cardiovascular } \\
\text { disease, alcohol consumption, body mass } \\
\text { index, family history, level of education }\end{array}$ & $\begin{array}{l}\mathrm{CAL}, \mathrm{PD}, \mathrm{PI} \\
\mathrm{Gl}, \mathrm{DMFT} \\
\text { radiographic } \\
\text { bone loss }\end{array}$ & $\begin{array}{l}3 \text { days } \\
\text { after }\end{array}$ & $\begin{array}{l}\text { Ischemic } \\
\text { stroke }\end{array}$ & $\begin{array}{l}\text { With the growth of CAL } \\
\text { increased risk of ischemic } \\
\text { stroke. }\end{array}$ \\
\hline $\begin{array}{l}\text { Grau et al.(50) } \\
2004\end{array}$ & $\begin{array}{l}771 \text { patients aged } 18-75 \\
303 \text { ischemic stroke, } \\
\text { transient ischemic; } \\
468 \text { - control group }\end{array}$ & $\begin{array}{l}\text { Age, gender, hypertension, smoking, } \\
\text { diabetes, hyperlipidemia, heart disease, } \\
\text { atrial fibrillation, alcohol consumption, } \\
\text { level of education, family history }\end{array}$ & $\begin{array}{l}\mathrm{CAL}, \mathrm{Gl} \text {, } \\
\mathrm{PI}, \mathrm{DMFT} \\
\text { radiographic } \\
\text { bone loss }\end{array}$ & $\begin{array}{l}\text { One week } \\
\text { after }\end{array}$ & $\begin{array}{l}\text { Ischemic } \\
\text { stroke }\end{array}$ & $\begin{array}{l}\text { Periodontitis increases the } \\
\text { risk of ischemic stroke in men } \\
<60 \text { years. }\end{array}$ \\
\hline $\begin{array}{l}\text { Pradeep et al. } \\
(46) \\
2009\end{array}$ & 200 patients aged $33-68$ & $\begin{array}{l}\text { Age, gender, diabetes, hypertension, } \\
\text { smoking, alcohol consumption, } \\
\text { cholesterol, level of education, family } \\
\text { history, diet }\end{array}$ & $\begin{array}{l}\mathrm{PI}, \mathrm{Gl}, \mathrm{PD}, \\
\mathrm{CAL}\end{array}$ & $\begin{array}{l}\text { About } 5 \\
\text { days after }\end{array}$ & $\begin{array}{l}\text { Ischemic } \\
\text { stroke }\end{array}$ & $\begin{array}{l}\text { Periodontitis is an } \\
\text { independent risk factor for } \\
\text { ischemic stroke. }\end{array}$ \\
\hline $\begin{array}{l}\text { Budin et al. (12) } \\
2014\end{array}$ & $\begin{array}{l}160 \text { patients } \\
80 \text { - patients after stroke } \\
80 \text { - control group }\end{array}$ & $\begin{array}{l}\text { Hypertension, heart disease, diabetes, } \\
\text { hyperlipidemia, kidney disease }\end{array}$ & $\begin{array}{l}\mathrm{PD}, \mathrm{Gl}, \mathrm{OHI} \\
\text { DMFT }\end{array}$ & ------- & Stroke & $\begin{array}{l}\text { Periodontitis occurred more } \\
\text { frequently in patients after } \\
\text { stroke. }\end{array}$ \\
\hline $\begin{array}{l}\text { Hashemipour et } \\
\text { al.(47) } \\
2013\end{array}$ & $\begin{array}{l}200 \text { patients } \\
100 \text { - patients after stroke } \\
100 \text { - control group }\end{array}$ & $\begin{array}{l}\text { Age, diabetes, hypertension, atrial } \\
\text { fibrillation, kidney disease, smoking, } \\
\text { cardiovascular disease }\end{array}$ & $\mathrm{Gl}, \mathrm{CAL}, \mathrm{PI}$ & $\begin{array}{l}\text { About } 3 \\
\text { days after }\end{array}$ & Stroke & $\begin{array}{l}\text { Periodontitis occurred more } \\
\text { frequently in patients after } \\
\text { stroke. }\end{array}$ \\
\hline
\end{tabular}

\section{CONCLUSIONS}

Four cohort studies and seven case-control studies were analyzed in the present review. All the research confirmed that periodontitis is an independent risk factor for stroke. The studied groups differed in size from 95-29,584 individuals. The European population was analyzed in the two cohort studies $[5,14]$ and two case-control studies $[49,50]$. To our knowledge, no studies in this field has been performed in the Polish population. In terms of the quality of the evidence, cohort studies seem more valuable than case-control studies, as the observation of the subject is long-term and risk precedes the effect. However, the majority of the cohort studies, which were not included in the present analysis, were based on the surveys or decay-missing-filled (DMFT) index only, thus reducing the reliability of data and overestimating the real prevalence of periodontal disease in the cohort.

Conversely, diagnosis of periodontal disease was usually well-documented in the case-control studies. The authors performed clinical (gingival index, BoP, probing depth, CAL) and radiological (bone loss) periodontal examinations $[12,45,46,47,48,49,50]$. The methodological differences were also demonstrated at the level of stroke diagnosis. Some researchers focused on ischemic stroke, binding its occurrence to the formation of atherosclerotic plaque [45, $46,49,50]$. Other researchers mentioned only a history of stroke in their patients [12, 14, 47, 48].

Recent meta-analysis that analyzed five case-control and three cohort studies showed a statistically significant association between periodontitis and ischemic stroke in both cohort pooled relative risks at $2.52(1.77-3.58)$, and case-control studies pooled relative risks at 3.04 (1.10-8.43) [51]. Although interventional studies in stroke are lacking, the available results suggest that adequate prevention and treatment of periodontal disease can reduce the incidence of stroke.

\section{REFERENCES}

1. Offenbacher S: Periodontal diseases: pathogenesis. Ann Periodontol 1996, 1: 821-878.

2. Bosnjak A, PlanËak D, Curilovî̂ Z. Advances in the Relationship between Periodontitis and Systemic Diseases.Acta Stomat Croat 2001; 267-271.

3. Lalla E, Lamster IB, Hofmann MA, Bucciarelli L, Jerud AP, Tucker S, Lu Y, Papapanou PN, Schmidt AM. Oral Infection With a Periodontal Pathogen Accelerates Early Atherosclerosis in Apolipoprotein E-Null Mice.Arterioscler Thromb Vasc Biol.2003;23:1405-1411.

4. Lafon A, Pereirac B, Dufourd T, Rigoubye V, Giroud M, Bejot Y, TubertJeannine S. Periodontal disease and stroke: a meta-analysis of cohort studies. European Journal of Neurology 2014, 21: 1155-1161.

5. Górska R, Konopka T, Banach J, Czochrowska E, Dembowska E, Friedwald E, Różyło-Kalinowska I, Ziętek M. Periodontologia współczesna. Wydanie I, Otwock 2013, ISBN 978-83-87717-18-6.

6. Mustapha IZ, Debrey S, Oladubu M, Ugarte R. Markers of systemic bacterial exposure in periodontal disease and cardiovascular disease risk: a systematic review and meta-analysis. J Periodontol 2007; 78: 2289-2302.

7. Romagna C, Dufour L, Troisgros O, et al. Periodontal disease: a new factor associated with the presence of multiple complex coronary lesions. J Clin Periodontol 2012; 39: 38-44.

8. You Z, Cushman M, Jenny NS, Howard G. Tooth loss, systemic inflammation, and prevalent stroke among par- ticipants in the Reasons for Geographic and Racial Dif- ference in Stroke (REGARDS) study. Atherosclerosis 2009; 203: 615-619.

9. Szczeklik A, Interna Szczeklika2015,Kraków 2015, ISBN 978-83-7430459-7.

10. Yoshida M, Akagawa Y. The relationship between tooth loss and cerebral stroke. Japanese Dental Science Review 2011;47;157-160.

11. Joshipura $K$. The relationship between oral conditions and ischemic stroke and peripheral vascular disease. J Am Dent Assoc. 2002; 133-23S 30S. 
12. Budin S, Azzuar RAM, Basri R, Alam MK, Masudi SM, Bhaskar S.Clinical Scenario and Oral Health Status in Stroke Patient. IMJ. 2014; 21(2): 156-159.

13. Grabowska-Fudala B, Jaracz K, Górna K, Zapadalność śmiertelność i umieralność z powodu udarów mózgu aktualne tendencje i prognozy na przyszłość, Przegl Epidemiol 2010; 64: 439-442

14. Söder B, Meurman JH, Söder P. Gingival Inflammation Associates with Stroke - A Role for Oral Health Personnel in Prevention: A Database Study. Plos one 2015;10(9);e0137142. doi:10.1371/journal.pone.0137142.

15. Bodnar DC, Varlan CM, Varlan V, Vaideanu T, Popa MB. Dental management in stroke patients.TMJ. 2008; 58;3-4;228-235.

16. Syrjanen J, Peltola J, Valtonen V, Iivanainen M, Kaste M, Huttunen JK. Dental infections in association with cerebral infarction in young and middle-aged men. J Intern Med 1989; 225: 179-184.

17. Ganowicz E, Błach A, Klamczyńska E, Franke E, Górska R.Analiza zależności między stanem klinicznym przyzębia a stopniem zaawansowania miażdżycy naczyń tętniczych. Dent. Med. Probl. 2008, 45, 2, 141-148.

18. Domagała W, Chosia M, Urasińska E.Podstawy patologii. Wydanie I, Warszawa 2010, ISBN 978-83-200-3499-8.

19.Zaremba M, Górska R, Suwalski P.Ocena występowania bakterii związanych z chorobą przyzębia w blaszce miażdżycowej naczyń wieńcowych. Czas. Stomat; 2005;LVIII;5;293-301.

20. Jóźwicka M, Głąbiński A.Patogeneza rozwoju blaszki miażdżycowej w tętnicach szyjnych. Aktualn Neurol 2011, 11 (4), p. 265-273.

21.Zaremba M, Leszczyński J,Górska R.The role of periopathogens in pathogenenesis of atherosclerotic disease. Acta Angiol 2012; 18, 3: 99-109.

22. Rose LF, Mealey B, Minsk L, Cohen L. Oral care for patients with cardiovascular disease and stroke. JADA;2002; 133;37s-44s.

23. Cotti E, Dessi C, Piras A, Mercuro G. Can a chronic dental infection be considered a cause of cardiovascular disease? IJCA; 2010;12803;7.

24. Perttu J. Lindsberg, Armin J. Grau.Inflammation and Infections as Risk Factors for Ischemic Stroke.Stroke. 2003; 34:2518-2532.

25. Żebrowski MR, Wójcicka A, Prociów A, Peterson-Jęckowska R.Wpływ przewlekłego zapalenia przyzębia na występowanie chorób układu sercowo-naczyniowego. Forum Kardiologów 2003; 8(2): 63-65.

26. Monteiro AM, Jardini MAN, Alves S, Giampaoli V,Aubin E, Neto AMF, Gidlund M. Cardiovascular Disease Parameters in Periodontitis. J Periodontol. 2009; 80(3):378-388.

27. Cueto A, Mesa F, Bravo M, Ocana-Riola R. Periodontitis as risk factor for acute myocardial infarction. A case control study of Spanish adults. J Periodont Res. 2005; 40: 36-42.

28. Grau AJ. Infection, inflammation, and cerebrovascular ischemia. Neurology 1997;49(Suppl 4):S47-S51.

29. Lee H, Garcia RI, Janket S, Jones JA,Mascarenhas AK,Scott TS,Nunn ME.The Association Between Cumulative Periodontal Disease and Stroke History in Older Adults.J Periodontol 2006;77;1744-1754.

30. Caula AL, Lira-Junior R, Tinoco EMB, Fischer RG. The effect of periodontal therapy on cardiovascular risk markers: a 6-month randomized clinical trial. J Clin Periodontol 2014; 41: 875-882.

31. Schoor R,Kano G.Periodontal Links to Systemic Disease. Dental News. 2002; 9(1): 21-23.

32. Buhlin K, Gustafsson A, Pockleyd A G, Frostegard J, Klinge B. Risk factors for cardiovascular disease in patients with periodontitis. European Heart Journal 3003; 24: 2099-2107.

33. Lockhart PB, Bolger AF, Papapanou, Osinbowale O, Trevisan M, Levison ME, Taubert KA, Newburger JW, Gornik HL, Gewitz $\mathrm{MH}$, Wilson WR, Smith SC, Baddour LM.Periodontal Disease and
Atherosclerotic Vascular Disease: Does the Evidence Support an Independent Association? A Scientific Statement From the American Heart Association.Circulation. 2012; 125: 2520-2544.

34. Grau AJ, Ling P,Palm F, Urbanek Ch,Becher H,Buggle F.Childhood and Adult Social Conditions and Risk of Stroke. erebrovasc Dis. 2012; (33): 385-391.

35. Lindsberg PJ,Grau AJ.Inflammation and Infections as Risk Factors for Ischemic Stroke. Stroke. 2003; (34): 2518-2532.

36. Landau MB, Renni MS, Zalis MG, Spector N,Gadelha T.Coagulation factor XIII Tyr204Phe gene variant and the risk of ischemic stroke. Journal of Thrombosis and Haemostasis. 11: 1426-1438.

37. Scannapieco FA, Bush RB, Paju S. Associations between periodontal disease and risk for atherosclerosis cardiovascular disease and stroke. Ann Periodontol. 2003; (8):38-53.

38. Hujoel PP. Does chronic periodontitis cause coronary heart disease?JADA. 2002; 133;31S-36S.

39. Brafford WD, Scott TA.Periodontal medicine, part II: the relationship between periodontal disease, atherosclerosis, coronary heart disease, and stroke. Clinical update. 2005; 27;3.

40. Stokowska W.Związek choroby przyzębia z chorobami serca i naczyń. Czas. Stomatol. 2009; 62 (7): 554-561.

41. Tonetti MS, Claffey N. Advances in the progression of periodontitis and proposal of definitions of a periodontitis case and disease progression for use in risk factor research. Group C consensus report of the 5th European Workshop in Periodontology. J Clin Periodontol 2005; 32:210-213.

42. Lafon A, Tala S, Ahossi V, Perrin D, Giround M, Bejot Y. Association between periodontal disease and non-fatal ischemic stroke: a casecontrol study. Acta Odontologica Scandinavica. 2014; 72: 687-693.

43. Wu T, Trevisan M, Genco RJ, Dorn JP, Falkner KL, Sempos CT.Periodontal Disease and Risk of Cerebrovascular DiseaseThe First National Health and Nutrition Examination Survey and Its Follow-up Study.Arch Intern Med. 2000; 160(18):2749-2755.

44. Jimenez M, Krall EA,Garcia RI, Vokonas PS, Dietrich T.Periodontitis and incidence of cerebrovascular disease in men. Ann Neurol. 2009 October; 66(4): 505-512.

45. Abolfazi N, Ghoreishizadeh A, Ayramlu H, Ghavimi M, G Ghoreishizadeh M, Salehsaber F. Periodontal Disease and Risk of Cerebral Ischemic Stroke. J Neurol.Sci 2011;28;307-316.

46. Pradeep AR, Hadge P, Arjun Raju P, Shetty SR, Shareef K, Guruprasad CN.Periodontitis as a risk factor for cerebrovascular accident: a casecontrol study in the Indian population.J Periodont Res. 2010; 45: 223-228.

47. Hashemipour MA, Afshar AJ, Borna R, Seddighi B, Motamedi A.Gingivitis and periodontitis as a risk factor for stroke: A casecontrol study in the Iranian population. Dental Research Journal. $2013 ; 10 ; 5 ; 613-619$.

48. Sim S-J, Kim H-D, Moon J-Y, et al. Periodontitis and the risk for nonfatal stroke in Korean adults. J Period- ontol 2008; 79: 1652-1658.

49. Dorfer CE, Becher H, Ziegler CM, Kaiser C, Lutz R, Jorb D, Lichy C, Buggle F, Bultmann S, Preusch M, Grau AJ: The association of gingivitis and periodontitis with ischemic stroke. J Clin Periodontol 2004; 31: 396-401.

50. Grau AJ, Becher H, Ziegler CM, et al. Periodontal disease as a risk factor for ischemic stroke. Stroke 2004; 35: 496-501.

51.Leira Y, Seoane J, Blanco M, Rodríguez-Yáñez M, Takkouche B, Blanco J, Castillo J. Association between periodontitis and ischemic stroke: a systematic review and meta-analysis. Eur J Epidemiol. 2017; 32:43-53 